\title{
Modeling landfill site selection using an integrated fuzzy MCDM approach
}

\author{
Manoj Govind Kharat ${ }^{1} \cdot$ Sheetal Jaisingh Kamble ${ }^{1} \cdot$ Rakesh D. Raut $^{1}$ • \\ Sachin S. Kamble ${ }^{1} \cdot$ Sudheer M. Dhume $^{1}$
}

Received: 17 February 2016/Accepted: 8 March 2016/Published online: 23 March 2016

(C) Springer International Publishing Switzerland 2016

\begin{abstract}
Landfill site selection is a complex process, which requires the evaluation of multiple criteria. Decision-makers often face difficulties in taking the right decision in a multiple attribute environment. In this paper, an integrated fuzzy-analytical hierarchy process (AHP)-the technique for order preference by similarity to ideal solution (TOPSIS)-based methodology was applied to the municipal solid waste (MSW) landfill site selection problem. To demonstrate the approach taken, a real case of Mumbai city is taken. The model was developed to suit the socio-economic and regulatory set-up. The fuzzy-analytic hierarchy process was used to make pairwise comparisons of criteria to assign weights and rank them, while F-TOPSIS was employed to rank the alternatives. It was found that the fuzzy-AHP-TOPSIS-based methodology can be a powerful guiding tool for MSW management planners. With this modeling approach, the accuracy of landfill site selection procedure can be significantly enhanced as compared to the traditional methods, thereby reducing the cost and time required. The developed methodology helps in representing and analyzing the uncertainty and error in the decision making process of landfill site selection.
\end{abstract}

Manoj Govind Kharat

manojgkharat@gmail.com

Sheetal Jaisingh Kamble

sheetaljkamble@gmail.com

Rakesh D. Raut

rakeshraut09@gmail.com

Sachin S. Kamble

sachinnitie06@gmail.com

1 National Institute of Industrial Engineering (NITIE), Powai, Mumbai, Maharashtra 400087, India
Keywords Municipal solid waste management - Landfill siting · MCDM · Fuzzy logic · Fuzzy-AHP · FuzzyTOPSIS

\section{Introduction}

Landfill site selection is a complex problem and requires an extensive evaluation process that has to be carried out taking into account the environmental, economic, sociopolitical, and legislative aspects. Landfill sites are considered as undesirable or obnoxious facilities and are usually opposed socially (Rodriguez et al. 2006; Colebrook and Sicilia 2007). Due to the scarcity of land and increasing amount of waste, it is vital that the available land resources are used with proper planning.

During the siting process, the challenge is to make an environment friendly and financially sound selection. Siting a suitable landfill location involves the consideration of a wide array of points, taking into account different criteria and verifying a given set of limitations to ultimately provide an optimal solution. The inability to properly site landfills has led to a great deal of controversy and negative effects. Public awareness of environmental impacts, and distrust for scientific studies to determine proper siting locations certainly leave waste managers with little room for error.

Until recently, there were no engineered landfill sites in India. As construction and management of landfills are quite expensive and need professional management, scientific location of landfills has not been actively considered in India. Most of the Indian cities, including the populated metros Mumbai and Delhi, do not have scientifically identified landfill sites. Indian metro cities generate an enormous amount of waste, containing $50-70 \%$ of 
biodegradables, 5-10\% of inert materials and 10-20\% recyclable waste. More than $90 \%$ of the municipal solid waste (MSW) generated in India is directly disposed of by dumping in low-lying areas or the land designated for this purpose within or outside the city, in an unscientific and unsatisfactory manner (Das et al. 1998). The selected disposal sites are mostly close to the collection area, and less attention is given to the siting of new sites. In several municipalities, existing landfill sites have already been exhausted and the respective local bodies do not have the resources and expertise to acquire new land. This significantly decreases their MSW collection efficiency. Also, in the existing sites, there is no provision for leachate and gas control, and soil cover is rarely provided except at the time of closure of the site. As a result, the landfills create severely unhygienic conditions and cause the degradation of environmental quality.

It is difficult to find suitable land to develop a landfill site that is close to the waste source. Economic concerns play an important role when the waste is to be transported at a distant site. Furthermore, from an economic perspective, the available land must be accessible through road networks. However, the location of landfill sites on or too close to existing road and rail networks can also hinder transportation and may have an impact on land price and tourism in the area. Thus, the landfill site should be located at an adequate distance for economic feasibility; contrastingly, they must be sufficiently far from the waste source to avoid social conflict.

Siting, design, construction, operation, and maintenance of an MSW landfill site need a financial plan for its longterm workability. Further, the location of a site should be such that it is possible to make technological changes in the landfill design and operation, and support post-closure care monitoring. In selecting a landfill site, many potential criteria and factors should be carefully identified, evaluated and analyzed; these include the distance from residential areas, selection of the optimal transportation routes, environmentally sensitive areas, geological features, and the cost of land. Thus, landfill site selection involves multiple criteria and can be viewed as a multiple criteria decision making (MCDM) problem.

Due to uncertainty and impreciseness of available information, apart from the ambiguity of human preferences, it is difficult to get accurate numerical values for the evaluation criteria. Therefore, most of the selection factors cannot be given correctly; this may hamper the evaluation process for decision-makers. In the current study, an integrated fuzzy analytical hierarchy process (AHP)-the technique for order preference by similarity to ideal solution (TOPSIS) methodology has been used to identify an optimal landfill site for MSW disposal. To demonstrate the approach taken, a real case of Mumbai city is taken. The evaluation criteria are determined based on international standards used in landfill siting. The fuzzy-AHP procedure is used to incorporate the decision-maker's opinions on the relative importance of the selection criteria. TOPSIS provides the advantage of simultaneous consideration of various criteria with different units. In this study, fuzzyTOPSIS is used to convert qualitative data to fuzzy numbers, which are then used in the calculations to rank the best alternative site. The study identifies a minimal optimal set of criteria for landfill site selection, which reduces the time taken in the decision making process. The developed methodology effectively takes into account the uncertain, subjective and linguistic data from expert opinions, providing more logical and precise results. Significantly, a literature survey revealed that no Indian study had made use of fuzzy MCDM methods considering uncertainty for landfill site selection.

The structure of the paper is as follows: "Introduction" of the paper introduces the landfill siting problem and accentuates the need of MCDM tools. In "Literature review", a brief literature review of previous papers reporting the use of any kind of MCDM technique in a landfill location-related problem has been presented. In "Materials and methods" a short description of the underlying theories has been presented; this has been followed by the main siting criteria used in this study. Finally, the results from the analysis are discussed in "Results and discussion" and conclusions are outlined in "Conclusion".

\section{Literature review}

The disposal facility siting problem in waste management has been studied by many researchers globally using MCDM techniques alone or in combination with other techniques. Many authors have applied multiple objective techniques in the waste facility location analysis (Stowers and Palekar 1993; Erkut and Verter 1995; Current and Ratick1995). Also, facility location models have been widely used for locating waste landfill sites to minimize exposure to the public and ecosystem.

Cheng et al. (2002) addressed the need for using MCDM methodologies in solid waste management systems because these systems can have complex and conflicting impacts on different stakeholders. Harvey and O'Flaherty (1973) developed a model, which determines the optimal locations of the landfill sites as well as the locations of the transfer stations. They applied their model on a 14 district problem that had 5 alternative sites for the transfer stations and 3 possible landfill sites.

In another study by Erkut and Moran (1991), the researchers developed an AHP-based decision modeling procedure that can be used by decision-makers to locate 
obnoxious facilities. They also demonstrated the applicability of the procedure in an analysis of recent decisions to locate a landfill site for the city of Edmonton, Alberta, Canada. A model to locate a treatment facility for hazardous wastes was developed by Stowers and Palekar (1993). Ramu and Kennedy (1994) applied a heuristic algorithm for locating a solid waste disposal site. A mixedinteger programming model was proposed by Kao and Lin (1996) to obtain a suitable landfill site. Siddiqui et al. (1996) used geographical information system (GIS) in combination with AHP for determining the suitability of land for a landfill site. In another study, fuzzy set theory was combined with GIS by Charnpratheep et al. (1997) for the screening of landfill sites in Thailand. Giannikos (1998) proposed a multiple objective model based on goal programming technique for locating disposal and treatment facilities for hazardous waste. In Portugal, Antunes (1999) developed a mixed integer optimization model combining the elements of a p-median model and a capacitated location model for locating the landfill sites. The developed model was used by decision-makers during the actual locating process in the Portuguese Centro region for minimizing the cost objective problem. Nema and Gupta (1999) developed a model using a multi-objective integer programming method to determine the optimal configuration of a hazardous waste management system. Chang and Wei (2000) developed a model for optimal features that should be considered in the solid waste collection network and landfill location, using fuzzy multi-objective nonlinear integer programming. Mahler and De Lima (2003) proposed a value analysis and fuzzy logic-based methodology for the selection of ideal landfill sites by assessing and ranking a predefined pool of objects. Vasiloglou (2004) presented a decision making process for the potential location of new suitable landfill sites with wide community participation. This study proposed a comprehensive set of criteria for the potential sites. Rakas et al. (2004) developed a multiple objective programming model utilizing the fuzzy linear programming approach for identifying unwanted facility locations. Al-Jarrah and Abu-Qdais (2006) proposed a methodology based on fuzzy sets for ideal MSW landfill sites. Şener et al. (2006) used integrated GIS and MCDM method, providing an efficient tool to solve the landfill site selection problem; here, GIS provided effective manipulation and presentation of the data and MCDM supplied consistent ranking of the potential landfill areas based on a variety of criteria.

In addition to these studies, Hung et al. (2006) and Cram et al. (2006) provided a viewpoint for the use of multicriteria decision making techniques in the related research area. Önüt and Soner (2008) applied a fuzzy TOPSIS methodology to solve the transhipment site selection problem in Istanbul, Turkey. The criteria weights were calculated using the AHP procedure. Similarly, AragonésBeltrán et al. (2010) in Spain used ANP and AHP for siting of suitable locations for a landfill. Geneletti (2010) applied the MCDM technique of simple additive weighting for landfill locations in Italy. Babalola and Busu (2011) attempted to determine a suitable landfill location through multi-criteria decision such as ANP. Aydi et al. (2013) employed fuzzy AHP, ELECTRE and the weighted linear combination method with GIS for landfill site selection; GIS was used for the screening of sites. More recently, Makan et al. (2012, 2013) applied PROMETHEE for suitable waste disposal site selection. AHP in combination with GIS was used by Alavi et al. (2013) for landfill site selection.

The following section of paper surveys and summarizes the work done world-wide in locating landfill sites using MCDM techniques in chronological order. Table 1 outlines the trend in the use of MCDM techniques in landfill siting. Table 1 highlights the main aspects and the contributions. The selected studies are segregated on the basis of the study area, techniques used, criteria used, and objective of the study. The survey does not include the studies that dealt with the collection and transportation problems, and hazardous waste. Most of the studies surveyed includes the combination of multi-criteria decision making tools. The studies consist of multiple criteria which are generalized mainly into four dimensions as social, technical, economic and environmental criteria in Table 1.

The major focus of survey table was on the evolution of the landfill siting problem and the trend in using MCDM tools for it. In the past, the studies mainly used single objective linear, dynamic, mixed-integer programming techniques and vector optimization. In the early 1990s, the focus was on using multi-criteria decision making techniques such as AHP and outranking methods. In the mid1990s the trend moved to the use of GISs. In the late 1990s, most of the studies used the MCDM tools in combination with GISs which dealt with more complex problems with different types of constraints, allowing suitable and highly visual sensitivity analysis. At the dawn of the new century the researchers concentrated more on the fuzzy programming, which allows to translate qualitative assessment into quantitative data. Most of the earlier models were region specific, focusing only on the location of a single landfill site. But recently the trend changed with the improvements in modelling and increased computational power.

An overview of the above-mentioned studies amply accentuates that the multi-criteria decision-making methods such as AHP and fuzzy model have been introduced as applied and current models during the recent years and tangible results of the calculations of these models has been revealed. However, some of these studies did not take into account the supply of imprecise data and the uncertainty 


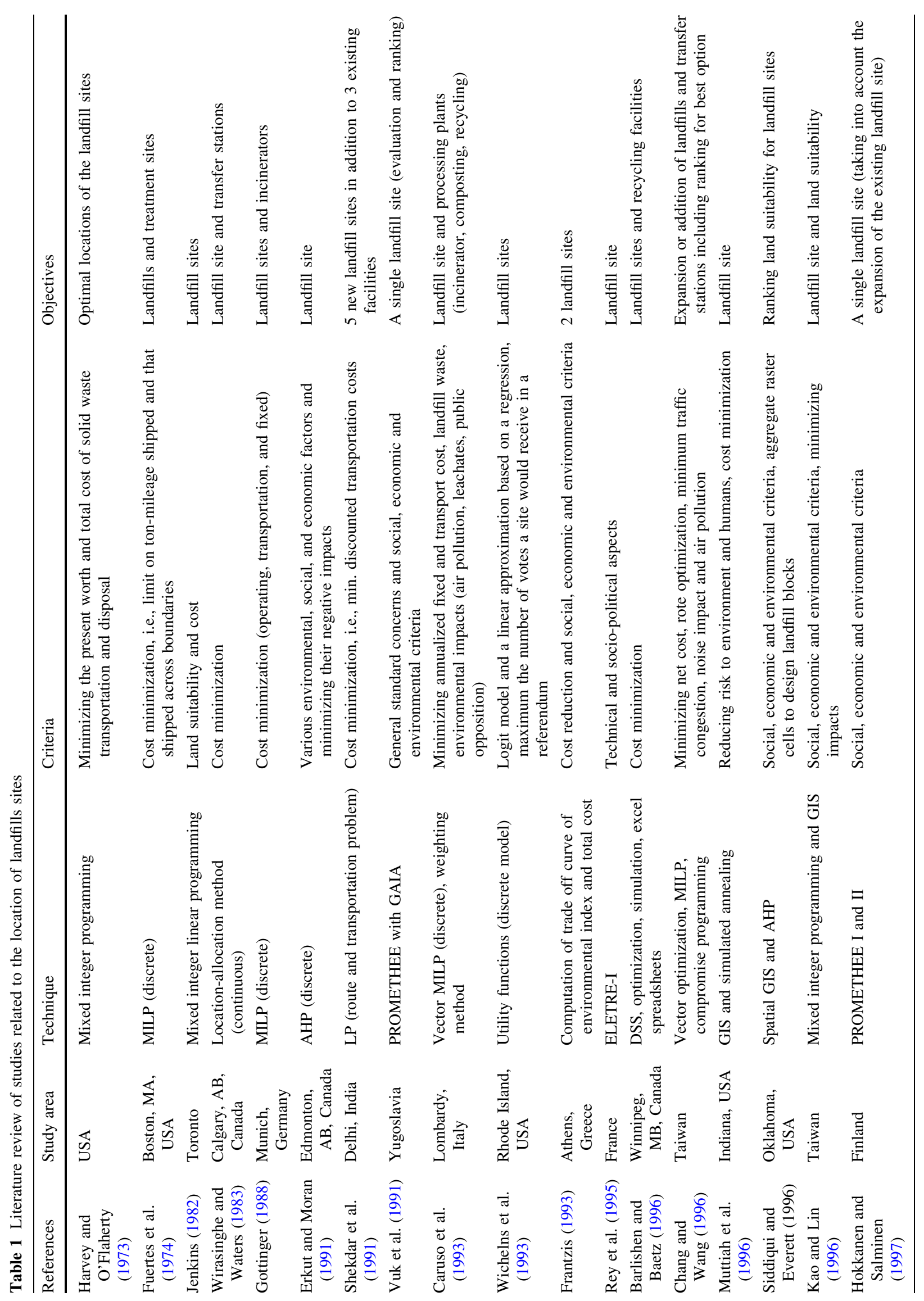




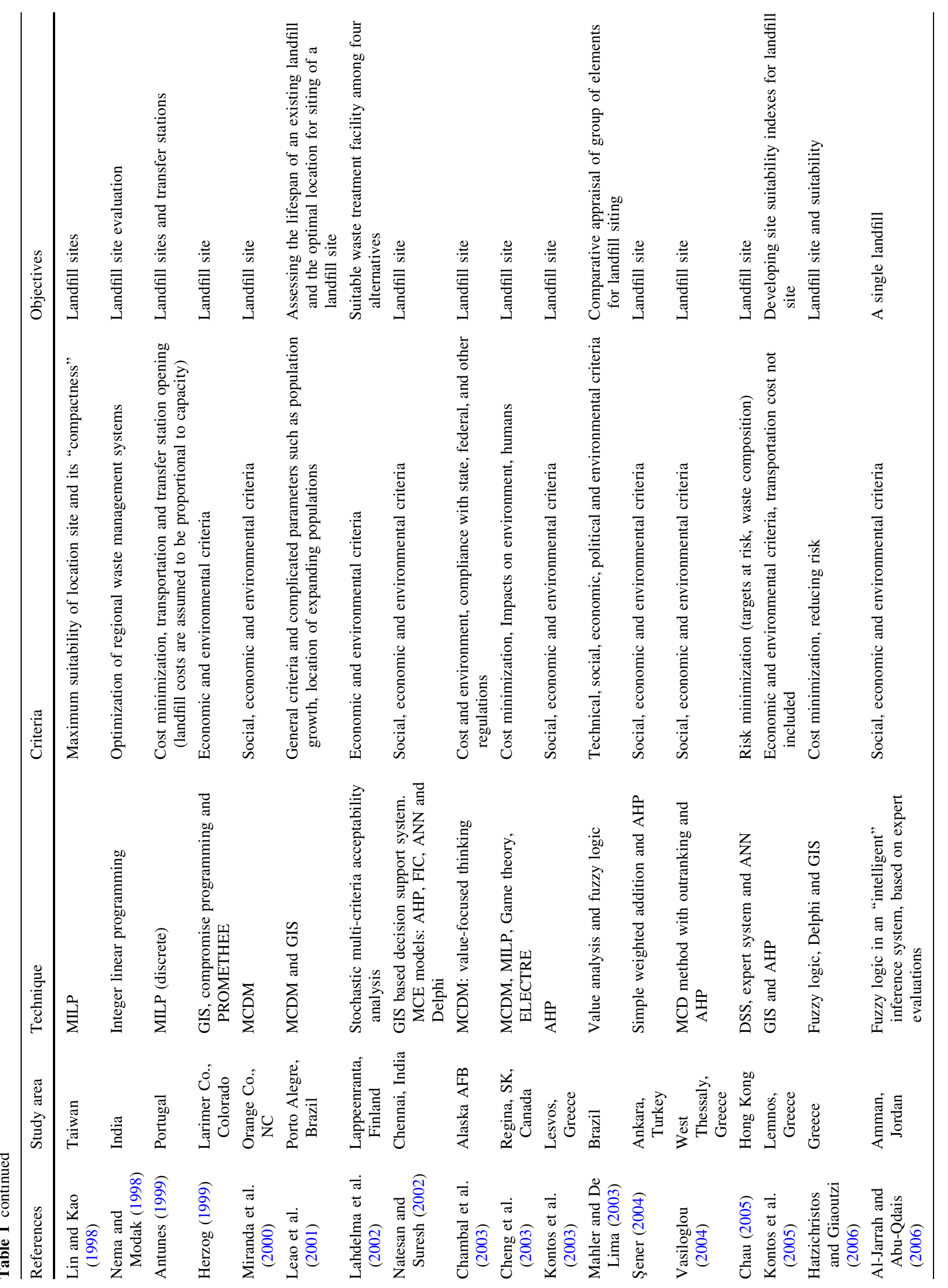




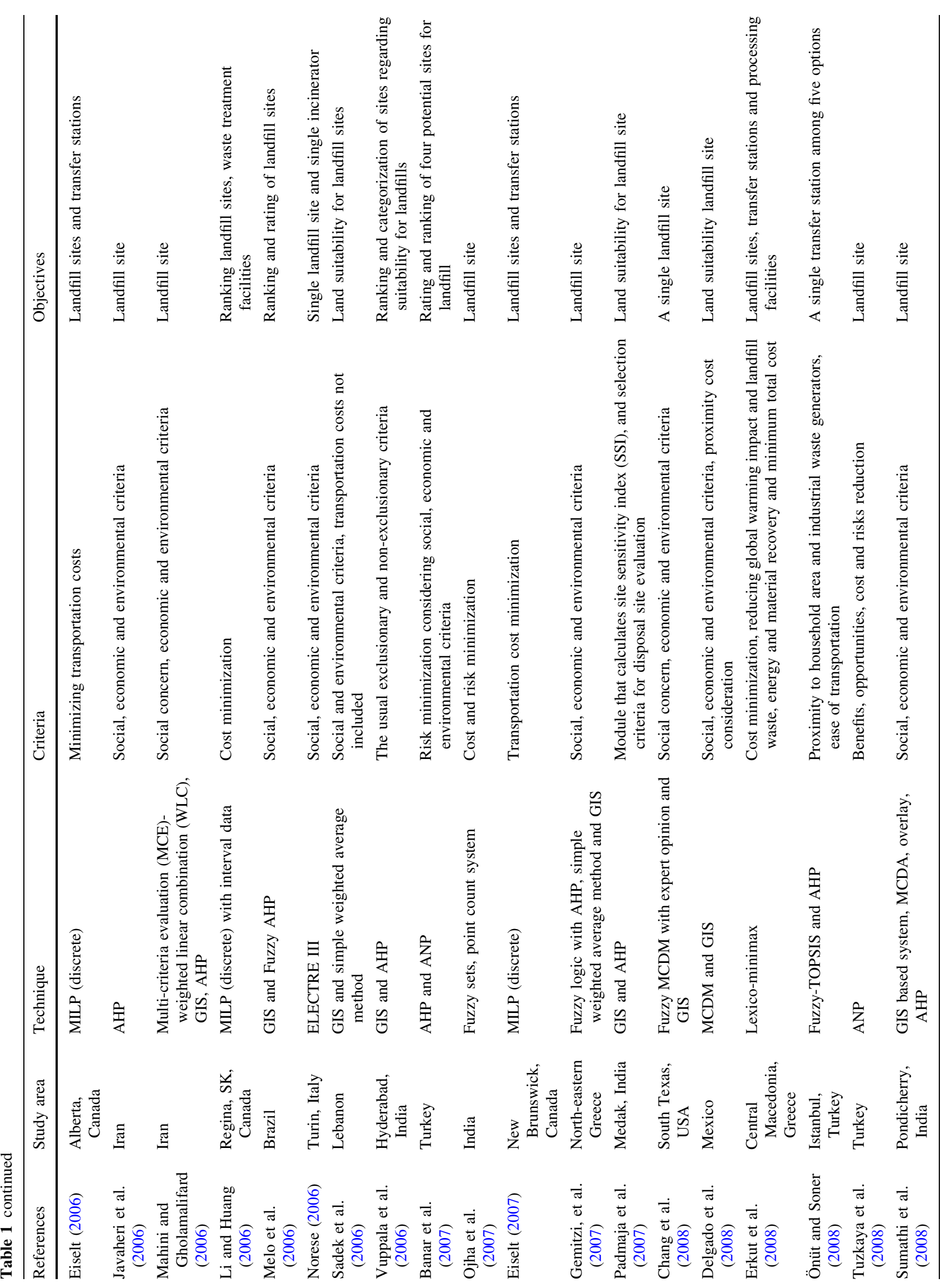




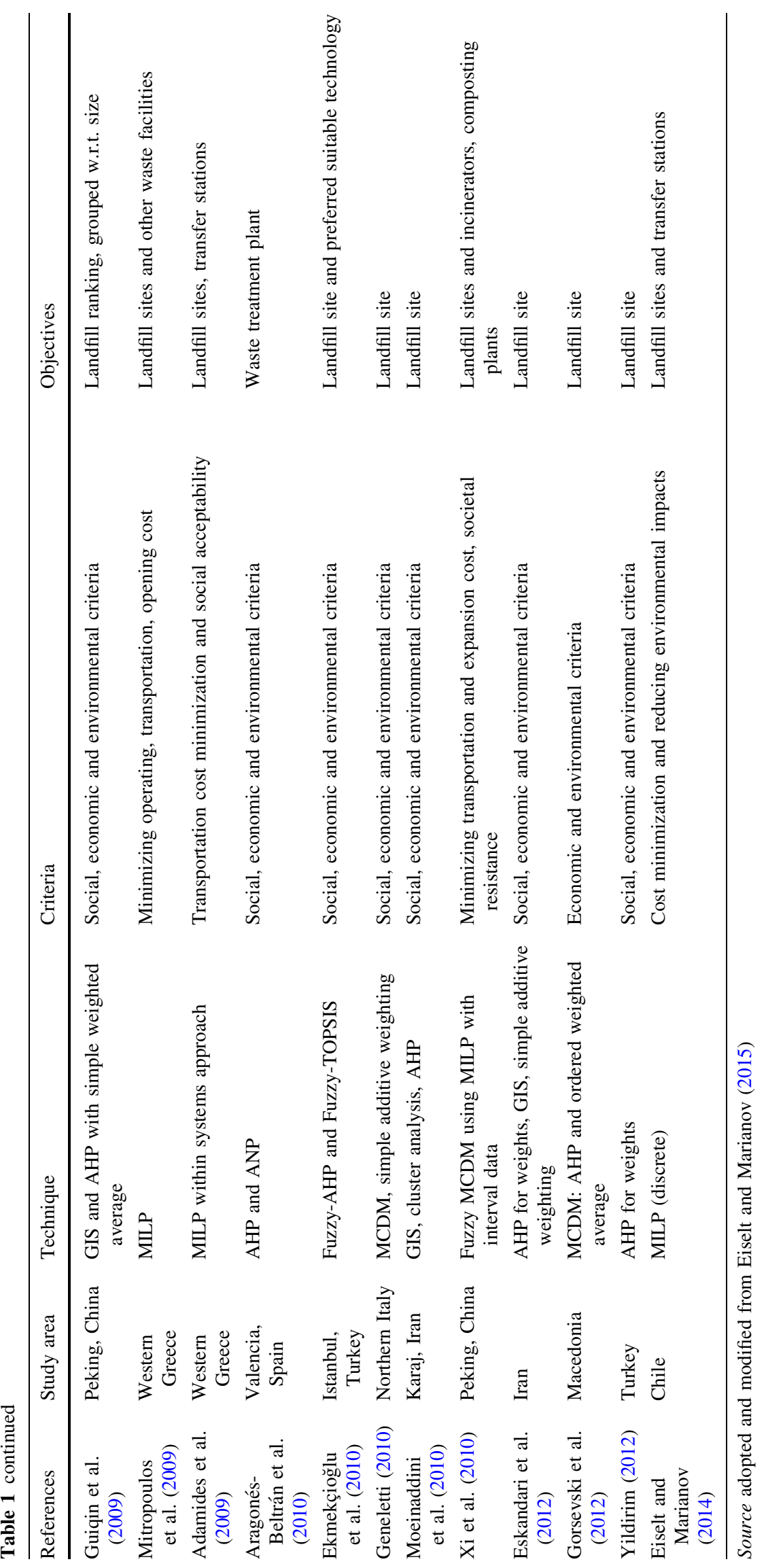


involved in the decision making process, apart from lacking logical interpretation. Importantly, none of the studies applied a fuzzy TOPSIS-based methodology in their studies. Therefore, to overcome these shortcomings, we combined fuzzy logic-based AHP and TOPSIS model to give more precise valuing of the subjective data and also to achieve results in a logical and scientific manner. Finally, the main objective was to locate an appropriate landfill site for the disposal of MSW. To demonstrate the approach taken, a real case of Mumbai city is taken.

\section{Materials and methods}

\section{Introduction of study area}

Mumbai, the financial capital of India, is located on the western coast and is a rapidly developing city. It is mainly a peninsula with geographical restrictions and enormous population pressure, leading to high land demand and land prices. In addition, Mumbai generates around 14,500 metric tonnes of MSW per day, $90 \%$ of which is dumped into landfills (MPCB 2014). It has three existing landfill sites, out of which two are already on the verge of closure. The existing landfill sites were identified merely according to convenience, with no scientific backing. They even violated legislations such as the coastal regulation zone notification (CRZ 2011). As a result, the selection and usage of these sites resulted in many politico-legal, socioeconomic and environmental problems. Also, being close to mangroves, they posed a serious threat to the fragile mangrove ecosystem.

The Mumbai city is divided into 24 wards with municipal boundaries. The city has a temperate continental climate influenced by the wet monsoon. The average annual rainfall is around $1,100 \mathrm{~mm}$. MCDM techniques have been applied in the study for identifying suitable landfill locations in Mumbai, considering the diverse features of the city and taking into account the requirements of minimizing error, reducing uncertainties and avoiding the violation of existing legislation.

\section{Analytic hierarchy process}

The AHP, developed by Saaty (1977) (Saaty 1980; Saaty and Vargas 2000), is a process designed for solving complex multiple criteria problems. AHP is a flexible decision making process to help decision-makers set priorities and make the best decision when both qualitative and quantitative aspects of a decision need to be taken into account.

Many researchers have concluded that AHP is a systematic method for ranking as it reduces complex decisions to a series of one-on-one comparisons, and then synthesizes the obtained results (Ting and Cho 2008). However, in many cases, the human preference model is uncertain and decision-makers might not be able to assign exact numerical values to the comparison judgments. For instance, when identifying different suitable locations, the decisionmakers are unsure about their level of choice due to incomplete, imprecise and uncertain information about possible locations and their performances. Also, due to subjective and qualitative site evaluation criteria, it is very difficult for the decision-makers to express the strength of their preferences, and to provide exact pairwise comparison judgments. For this reason, a methodology based on fuzzyAHP can help one reach an effective decision and the uncertainty and ambiguity involved in the decision making process can be dealt with.

AHP is also a popular method to determine the appropriate weights of the selected criteria, which is one of the problems faced during multi-criteria decision analysis. The AHP decomposes the decision process into a hierarchical structure and also deals with quantifiable and intangible criteria by using the pairwise comparison matrices. The breaking down of the decision problem into composite steps through AHP has been described in Table 2 (Chamodrakas et al. 2010; Raut et al. 2011).

Steps involved in the AHP method:

1. Define an objective of the problem and determine its goal.

2. Structure the hierarchy from the top (objectives from a decision-makers viewpoint) through intermediate levels (criteria, sub-criteria if any) to the lowest level, which contains a list of alternatives.

3. Employ a pairwise comparison approach.

Saaty (2000) developed the fundamental scale for pairwise comparisons, as shown in Table 2. The pairwise comparison matrix $\mathrm{A}$, in which the element $a_{i j}$ of the matrix is the relative importance of the $i$ th factor with respect to the $j$ th factor, can be calculated as

Table 2 Scale for pairwise comparisons (Saaty 1980)

\begin{tabular}{|c|c|}
\hline $\begin{array}{l}\text { Numerical } \\
\text { rate }\end{array}$ & Judgment \\
\hline 1 & Factor $i$ and $j$ are equal important \\
\hline 3 & Factor $i$ is weak important \\
\hline 5 & Factor $i$ is strong important \\
\hline 7 & Factor $i$ is demonstrated important \\
\hline 9 & Factor $i$ is absolute important \\
\hline $2,4,6,8$ & $\begin{array}{l}\text { Intermediate values between the two adjacent } \\
\text { judgments }\end{array}$ \\
\hline Reciprocal & $\begin{array}{l}\text { If the important rate of factor } i \text { to } j \text { is } R x y \text {, then the } \\
\text { important rate of factor } j \text { to } i \text { is } R y x=1 / R x y\end{array}$ \\
\hline
\end{tabular}




$$
A=\left[a_{i j}\right]=\left[\begin{array}{cccc}
1 & a_{12} & \cdots & a_{1 n} \\
1 / a_{12} & 1 & \cdots & a_{2 n} \\
\vdots & \vdots & \cdots & \vdots \\
1 / a_{1 n} & 1 / a_{2 n} & \cdots & 1
\end{array}\right]
$$

4. There are $n(n-1)$ judgments required for developing the set of matrices in step 3. Reciprocals are automatically assigned to each pairwise comparison, where $n$ is the matrix size.

5. Utilizing the hierarchical synthesis to weigh the eigenvectors according to the weights of criteria. The sum is for all weighted eigenvectors corresponding to those in the next lower hierarchy level.

6. Having made all pairwise comparisons, consistency is identified by using the eigenvalue. To calculate the consistency index (CI), Saaty (1990) proposed that the largest eigenvalue, $\lambda_{\max }$ will be

$$
\lambda_{\max }=\sum_{j=1}^{n} a_{i j} \frac{W_{j}}{W_{i}}
$$

where $\lambda_{\max }$ is the principal or largest eigenvalue of positive real values in a judgment matrix, $W_{j}$ the weight of $j$ th factor, $\mathrm{W}_{i}$ is the weight of $i$ th factor.

7. Conducting consistency test. Each pairwise comparison contains numerous decision elements for the CI, which measures the entire consistency judgment for each comparison matrix and the hierarchy structure. Saaty (1990) utilized the CI and consistency ratio (CR) to assess the consistency of the comparison matrix. The $\mathrm{CI}$ and $\mathrm{CR}$ are defined as

$$
\mathrm{CI}=\frac{\lambda_{\max }-n}{n-1}
$$

where $n$ is the matrix size.

$$
\mathrm{CR}=\frac{\mathrm{CI}}{\mathrm{RI}}
$$

The judgment consistency can be checked by taking the CR of CI with the appropriate value, as shown in Table 3. The CR is acceptable if it does not exceed 0.10. If the value of CR is $>0.10$, the judgment matrix is inconsistent. To acquire a consistent matrix, judgments should be reviewed and improved.

The AHP methodology has been demonstrated by applying it to a landfill site selection problem in this study.

\section{Fuzzy-analytic hierarchy process (F-AHP)}

In this study, the framework of the feasible regions of relative weights was adopted. Firstly, allowing the feasible region to include tolerance deviations of the fuzzy ratios, we defined fuzzy consistency as the existence of relative weights within the region. Secondly, we devised a maximum/minimum set ranking method to derive a crisp ranking from the global fuzzy weights. There are two main characteristics of fuzzy systems that allow them to give better performance for specific applications: (1) fuzzy systems are suitable for uncertain or approximate reasoning, especially for the system with a mathematical model that is difficult to derive; and (2) fuzzy logic allows decision making with estimated values under incomplete, imprecise or uncertain information. Hence, fuzzy logic was combined and used along with AHP, and resulted in a fuzzy-AHP methodology for reviewing and weighting the landfill site selection criteria.

The following steps of fuzzy-AHP proposed by Chang (1996) were utilized for selecting and ranking the criteria in the multi-period phase. According to the method of Chang's extent analysis, each object is taken and extent analysis for each goal is performed, respectively. Therefore, $m$ extent analysis values for each object can be obtained, with the following signs:

$M_{g^{i}}^{1}, M_{g^{i}}^{2}, \ldots, M_{g^{i}}^{m}, \quad i=1,2, \ldots, n$.

Where $M_{g^{i}}^{j}(j=1,2, \ldots, m)$ all are triangular fuzzy numbers (TFNs).

The steps of Chang's extent analysis (Chang 1996) are as follows:

1. The value of fuzzy synthetic extent with respect to the $i$ th object is defined as

$$
S_{i}=\sum_{j=1}^{m} M_{g^{i}}^{j} \otimes\left[\sum_{i=1}^{n} \sum_{j=1}^{m} M_{g^{i}}^{j}\right]^{-1}
$$

To obtain $\sum_{j=1}^{m} M_{g^{i}}^{j}$, the fuzzy addition operation of $\mathrm{m}$ extent analysis values for a particular matrix is performed as

$$
\sum_{j=1}^{m} M_{g^{i}}^{j}=\left(\sum_{j=1}^{m} l_{j}, \sum_{j=1}^{m} m_{j}, \sum_{j=1}^{m} u_{j}\right)
$$

Table 3 Average random consistency (RI)

\begin{tabular}{lllllllllll}
\hline Size of matrix & 1 & 2 & 3 & 4 & 5 & 6 & 7 & 8 & 9 & 10 \\
$\begin{array}{l}\text { Random } \\
\text { consistency }\end{array}$ & 0 & 0 & 0.58 & 0.9 & 1.12 & 1.24 & 1.32 & 1.41 & 1.45 & 1.49 \\
\hline
\end{tabular}


and to obtain $\left[\sum_{i=1}^{n} \sum_{j=1}^{m} M_{g^{i}}^{j}\right]$, the fuzzy addition operation of $M_{g^{i}}^{j}(j=1,2, \ldots, m)$ values is performed such that,

$\left[\sum_{i=1}^{n} \sum_{j=1}^{m} M_{g^{i}}^{j}\right]=\left(\sum_{i=1}^{n} l_{i}, \sum_{i=1}^{n} m_{i}, \sum_{i=1}^{n} u_{i}\right)$

and $\sum_{i=1}^{n} \sum_{j=1}^{m} M_{g^{i}}^{j}$ can be calculated by the inverse of Eq. (7), as follows:

$\left[\sum_{i=1}^{n} \sum_{j=1}^{m} M_{g^{i}}^{j}\right]^{-1}=\left(\frac{1}{\sum_{i=1}^{n} u_{i}}, \frac{1}{\sum_{i=1}^{n} m_{i}}, \frac{1}{\sum_{i=1}^{n} l_{i}}\right)$

2. As $M_{1}=\left(l_{1}, m_{1}, u_{1}\right)$ and $M_{2}=\left(l_{2}, m_{2}, u_{2}\right)$ are two TFNs, the degree of possibility of $M_{2}=\left(l_{2}, m_{2}\right.$, $\left.u_{2}\right) \geq M_{1}=\left(l_{1}, m_{1}, u_{1}\right)$ is defined as

$$
\begin{gathered}
V\left(M_{2} \geq M_{1}\right)=\sup \left\lfloor\min \left(\mu_{M_{1}}(x), \mu_{M_{2}}(y)\right)\right\rfloor \\
y \geq x
\end{gathered}
$$

and can be equally expressed as follows:

$$
\begin{aligned}
& V\left(M_{2} \geq M_{1}\right)=h g t\left(M_{1} \cap M_{2}\right)=\mu_{M_{2}}(d) \\
& = \begin{cases}1 & \text { if } m_{2} \geq m_{1} \\
0 & \text { if } l_{1} \geq u_{2} \\
\frac{\left(l_{1}-u_{2}\right)}{\left(m_{2}-u_{2}\right)-\left(m_{1}-l_{1}\right)} & \text { otherwise }\end{cases}
\end{aligned}
$$

Figure 1 (Chang 1996) shown below illustrates Eq. (10) where $d$ is the ordinate of the highest intersection point $D$ between $\mu_{M_{1}}$ and $\mu_{M_{2}}$. To compare $M_{1}=\left(l_{1}, m_{1}, u_{1}\right)$ and $M_{2}=\left(l_{2}, m_{2}, u_{2}\right)$, we need both the values of $V\left(M_{1} \geq M_{2}\right)$ and $V\left(M_{2} \geq M_{1}\right)$.

3. The degree possibility for a convex fuzzy number to be greater than $k$ convex fuzzy $M_{i}(i=1,2, \ldots, k)$ numbers can be defined by

$$
\begin{aligned}
V\left(M \geq M_{1}, M_{2}, \ldots, M_{k}\right)= & V\left[\left(M_{1} \geq M_{2}\right)\right. \text { and } \\
& \left.\left(M \geq M_{2}\right) \text { and. . and }\left(M \geq M_{k}\right)\right] \\
= & \min V\left(M \geq M_{i}\right), i=1,2, \ldots, k
\end{aligned}
$$

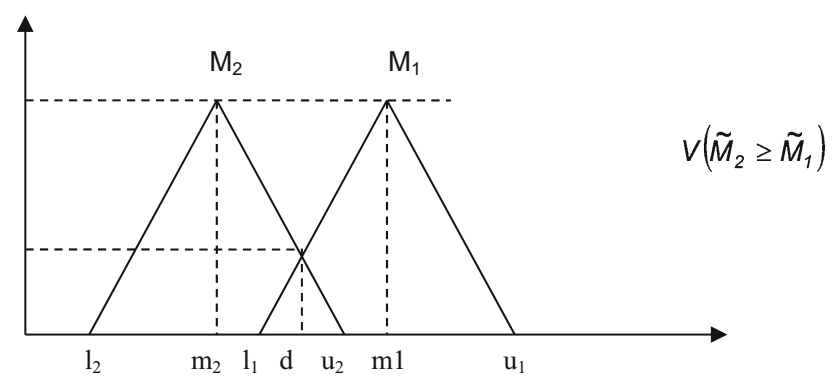

Fig. 1 Intersection between $M_{1}$ and $M_{2}$ (Kahraman et al. 2004)

Assume that

$d\left(A_{i}\right)=\min V\left(S_{i} \geq S_{k}\right)$ for $k=1,2, \ldots, n ; k \neq i$.

Then the weight vector is given by

$W^{\prime}=\left(d^{\prime}\left(A_{1}\right), d^{\prime}\left(A_{2}\right), \ldots, d^{\prime}\left(A_{n}\right)\right)^{\mathrm{T}}$

where $A_{i}(i=1,2, \ldots, n)$ are the $n$ elements.

4. After normalization, the normalized weight vectors are

$W=\left(d\left(A_{1}\right), d\left(A_{2}\right), \ldots, d\left(A_{n}\right)\right)^{\mathrm{T}}$

where $W$ is a non-fuzzy number.

\section{Fuzzy-TOPSIS}

The technique for order preference by similarity to ideal solution was developed for solving the MCDM problems by Hwang and Yoon (1981), based on the concept that the chosen/improved alternatives should be the shortest distance from the positive ideal solution (PIS) and the farthest from the negative-ideal solution (NIS) (Wu et al. 2009). After calculating the importance weights and ranking of criteria, a modified fuzzy-TOPSIS approach has been applied for conducting the ranking process of alternatives (Shih et al. 2007). The rationale of the fuzzy method is to defuzzify imprecise values at the end of the process, not from the beginning (Wang and Elhag 2006). Wang and Elhag (2006) developed a fuzzy TOPSIS method based on alpha-level sets to perform defuzzification at the very end of the decision analysis process.

To avoid complicated calculations and to improve the applicability of the proposed approach, we used the graded mean integration representation (GMIR) method proposed by Chen and Hsieh (2000) to obtain the final closeness coefficient of each alternative. The formulation of the F-TOPSIS was adopted from Jolai et al. (2011). In order to establish the fuzzy decision matrix, each decision-maker employed the linguistic variables shown in Table 4.

The step-by-step procedure of using the fuzzy-TOPSIS is listed as follows.

1. Establish the normalized performance matrix.

The purpose of normalizing the performance matrix is to merge the unit of matrix entries. Assume that the original performance matrix is

Table 4 Linguistic variables for ratings of alternatives with respect to each criterion

\begin{tabular}{ll}
\hline Very low & $(0,1,2)$ \\
Low & $(2,3,4)$ \\
Medium & $(4,5,6)$ \\
High & $(6,7,8)$ \\
Very high & $(8,9,10)$
\end{tabular}


$x=\left(x_{i j}\right) \quad \forall_{i, j}$

where $x_{i j}$ is the performance of alternative $i$ to criterion $j$.

2. Create the weighted normalized performance matrix.

TOPSIS defines the weighted normalized performance matrix as:

$\begin{array}{ll}V=\left(V_{i j}\right) & \forall_{i, j} \\ V_{i j}=w_{i j} \times r_{i j} & \forall_{i, j}\end{array}$

where $w_{j}$ is the weight of criterion $j$.

3. Determine the PIS and NIS.

The ideal solution is computed based on the following equations:

$$
\begin{aligned}
A^{+} & =\left\{\left(\max V_{i j} / j \in J\right),\left(\min V_{i j} / j \in J^{\prime}\right), i\right. \\
& =1,2, \ldots, m\} \\
A^{-} & =\left\{\left(\min V_{i j} / j\right),\left(\min V_{i j} / j \in J^{\prime}\right), i=1,2, \ldots, m\right\}
\end{aligned}
$$

where

$j=\{j=1,2, \ldots, n / j$ belongs to benefit criteria $\}$; $j=\{j=1,2, \ldots n / j$ belongs to cost criteria $\}$ :

4. Calculate the distance between PIS and NIS for each alternative:

$$
\begin{aligned}
& S_{i}^{+}=\sqrt{\sum_{j=1}^{n} w j \cdot\left(V_{i j}-V_{j}^{+}\right)^{2}} \quad i=1,2, \ldots, m \\
& S_{i}^{-}=\sqrt{\sum_{j=1}^{n} w j \cdot\left(V_{i j}-V_{j}^{-}\right)^{2}} \quad i=1,2, \ldots, m
\end{aligned}
$$

5. Calculate the relative closeness to the ideal solution of each alternative:

$$
C_{i}^{+}=\frac{S_{i}^{-}}{S_{i}^{+}+S_{i}^{-}} \quad i=1,2, \ldots, m
$$

where $0 \leq c_{i}^{*} \leq 1$ that is, an alternative $i$ is closer to $A_{i}^{*}$ as $C_{i}^{*}$ approaches to 1 .

6. Rank the preference order.

Using the GMIR method we can calculate the closeness coefficient of each alternative $A i, i=1,2, \ldots, m$ as follows:

$$
C C_{i}^{+}=\frac{C i 1+4 C i 2+C i 3}{6} \quad i=1,2, \ldots, m
$$

\section{Questionnaire development, validity and reliability}

In order to prioritize the landfill siting process in an Indian context, the siting criteria were obtained from the existing
Table 5 F-AHP scale

\begin{tabular}{ll}
\hline Definition & Intensity of importance \\
\hline Equal & $(1,1,1)$ \\
Weak & $(2 / 3,1,3 / 2)$ \\
Fairly strong & $(3 / 2,2,5 / 2)$ \\
Very strong & $(5 / 2,3,7 / 2)$ \\
Absolute & $(7 / 2,4,9 / 2)$ \\
\hline
\end{tabular}

literature and relevant standards. Using a fuzzy approach, the numerical value of each linguistic term used in the questionnaire was determined based on the fuzzy-AHP scale shown in Table 5 (Lin et al. 2006). Fuzzy logic ensures a precise mathematical approach to deal with the vagueness associated with the importance of a criterion or relative judgment of people. Fuzzy set theory acts as a very useful tool to address the uncertainty and imprecision issue, which affects the landfill site selection. As observed from Table 5, the solid 5 scale linguistic term has been transformed to equal fuzzy intervals.

\section{Selection of evaluation criteria}

Based on a review of the literature, evaluation criteria related to landfill site selection were identified. Then, expert questionnaires were used for screening the indexes fit for the landfill site selection process. Twelve siting indexes were selected by the committee of experts. The expert committee consisted of ten professionals from practice and five from the academia. The siting criteria (i.e., 12 indexes) used in the landfill site selection are shown in Table 6.

On the basis of the hierarchical framework of the siting indexes, the F-AHP questionnaire using fuzzy triangular numbers (FTN) was distributed among the experts for soliciting their professional opinions. The relative importance (fuzzy weight) of each criteria analysed by F-AHP is listed in Table 7.

\section{Results and discussion}

Three alternative sites $A 1, A 2$ and $A 3$, were taken as an illustrative example and were evaluated by the experts based on the screened evaluation criteria. Since there are differences of subjective judgments between the ways in which experts view each evaluation criterion, the overall evaluation of the fuzzy judgment was employed to synthesize the opinions of the various experts in order to achieve a reasonable and objective evaluation.

Each decision-maker establishes the fuzzy decision matrix in which each alternative is evaluated with respect 
Table 6 Criteria identified and used in the study

\begin{tabular}{|c|c|c|}
\hline Criteria & Abbr. & Definition \\
\hline Public acceptance & PA & The location identified should be accepted socially \\
\hline Hydrology & HY & Pollution of surface and ground water resources by leachate is a prime concern \\
\hline Climate & $\mathrm{CL}$ & $\begin{array}{l}\text { Wind and rain are common climatic factors influencing site selection, especially in the coastal areas. If the site is } \\
\text { exposed to strong winds, coastal disasters are a distinct possibility, and adequate coastal protection is a must. } \\
\text { Also, for high rainfall areas as in the case of Mumbai, to minimize leachate production, effective storm water } \\
\text { diversion is essential }\end{array}$ \\
\hline $\begin{array}{l}\text { Soil and } \\
\text { topography }\end{array}$ & SAT & $\begin{array}{l}\text { A suitable site will have a sufficient grade to provide drainage of surface runoff and adequate level areas to enable } \\
\text { excavation of trenches and associated earthworks and the construction of service facilities avoiding potential } \\
\text { ground water problems, soil erosion risk, access, and providing site visibility and protection from prevailing } \\
\text { winds. Sites with slopes exceeding 1:5 are generally not suitable because of the soil erosion risk }\end{array}$ \\
\hline Fracture and faults & FNF & Faulted zone locations should be avoided if possible \\
\hline Adjacent land use & ALU & $\begin{array}{l}\text { Existing and possible future developments adjacent to the site should be considered. Locations with higher } \\
\text { potential for nature conservation, agriculture and residential development should not be considered, e.g. } \\
\text { wetlands, etc }\end{array}$ \\
\hline Sensitive areas & SA & $\begin{array}{l}\text { Presence of airports, nuclear sites, electrical supply lines, oil ducts, petrochemical industries, etc. in the nearby } \\
\text { areas is not desirable }\end{array}$ \\
\hline $\begin{array}{l}\text { Habitat, flora and } \\
\text { fauna }\end{array}$ & HAF & $\begin{array}{l}\text { Sites having natural flora and fauna and habitation are unsuitable as the landfill can cause major disruption to them. } \\
\text { Control of vermin populations, bird, rodents and other animal pests is an important factor in maintaining both } \\
\text { public health and environmental stability }\end{array}$ \\
\hline Inter-municipality & INM & More than one municipality may use the facility, sharing building and maintenance costs \\
\hline Site capacity & $\mathrm{SC}$ & Identified sites should have enough capacity \\
\hline Cost & COS & Each location has its own cost value \\
\hline $\begin{array}{l}\text { Road network/ } \\
\text { access }\end{array}$ & RNA & $\begin{array}{l}\text { Direct access to the site so that waste is not dumped before getting to the landfill, and to minimize waste spillage, } \\
\text { traffic congestion and fuel usage of vehicles }\end{array}$ \\
\hline
\end{tabular}

Table 7 Fuzzy weights of performance evaluation index by F-AHP

\begin{tabular}{lllllcc}
\hline Criteria & $\alpha$ & $\beta$ & $\gamma$ & \multicolumn{2}{l}{ Best non-fuzzy performance } \\
\cline { 4 - 6 } & & & & \multicolumn{2}{l}{$[(U-L)+(M-L)] / 3+L$} & 10.30381074 \\
\hline Hydrology (HY) & 0.078273034 & 0.101978808 & 0.12886248 & 0.103038107 & 2 \\
Sensitive areas (SA) & 0.073189279 & 0.090645393 & 0.108895491 & 0.090910054 & 9.091005435 \\
Soil and topography (SAT) & 0.087195632 & 0.094615897 & 0.100205011 & 0.094005514 & 9.400551354 & 4 \\
Habitat and flora \& fauna (HAF) & 0.088215792 & 0.0956239 & 0.099016338 & 0.094285343 & 9.428534335 \\
Climate (CL) & 0.093057903 & 0.104275293 & 0.112047935 & 0.103127043 & 10.31270435 \\
Fracture and faults (FNF) & 0.070969262 & 0.07419064 & 0.078402389 & 0.074520764 & 7.4520764 \\
Public acceptance (PA) & 0.082237151 & 0.07526837 & 0.067493175 & 0.074999565 & 7.499956538 \\
Adjacent land use (ALU) & 0.073684553 & 0.070555984 & 0.067542988 & 0.070594508 & 7.059450843 & 1 \\
Intra-municipality (INM) & 0.080829767 & 0.073455331 & 0.063869715 & 0.072718271 & 7.271827108 & 10 \\
Cost of site (COS) & 0.08143124 & 0.071331433 & 0.060944339 & 0.071235671 & 7.123567057 & 11 \\
Road network/access (RNA) & 0.094282332 & 0.073268209 & 0.057220789 & 0.074923777 & 7.492377651 & 8 \\
Site capacity (SC) & 0.096634053 & 0.074790742 & 0.05549935 & 0.075641382 & 7.564138189 & 6 \\
\hline
\end{tabular}

to each criterion. Decision-makers use the linguistic variables shown in Table 4 to perform these evaluations. The ranking of these three alternatives by the decision-makers under each criterion, and the aggregated fuzzy decision matrix of the group is presented in Table 8 .

In this study, the five linguistic variables, "very low", "low", "medium" "high" and "very high", were used to measure the alternatives with respect to the evaluation criteria. As shown in Table 4, each linguistic variable is represented by a TFN in the range of $1-10$. The average fuzzy judgment values of each criterion of the three alternatives, integrated by various experts, calculated through Eqs. (12)-(15), are summarized in Table 8. The final fuzzy synthetic judgment of the three locations is derived from the fuzzy criteria weight (Table 7) and the fuzzy judgment values are calculated by Eqs. (15)-(20). 


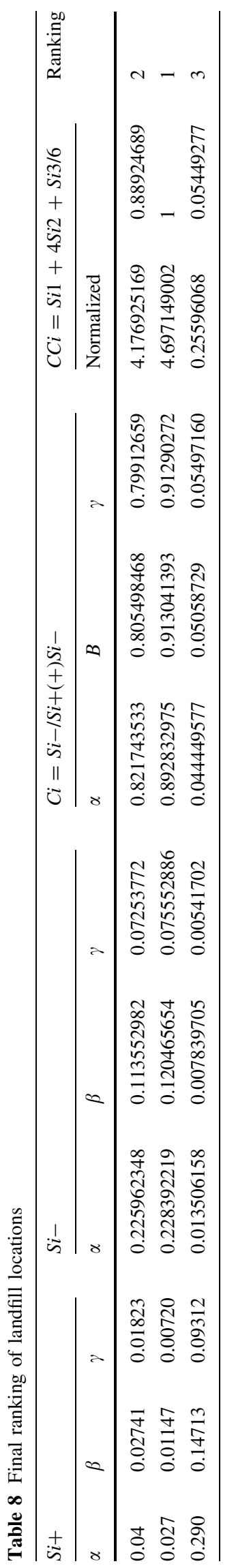

Table 8 presents the final fuzzy synthetic judgment of the three locations based on the evaluation criteria. Consequently, based on the fuzzy weights of the evaluation criteria calculated by F-AHP, the MCDM analytical tool F-TOPSIS is adopted to rank the alternative locations (Table 8). The fuzzy weights of the performance evaluation indexes, as calculated by F-AHP, have been shown in Table 7. The weighted normalized performance matrices are calculated by Eq. (17) and both PIS and NISs for the evaluation criteria are obtained through Eqs. (18a and 18b).

Table 8 lists the separations of the PIS Si+ and the negative-ideal solution $\mathrm{Si}$ - for the three alternatives calculated by Eqs. (19 and 20). The relative closeness $C i+$ to the ideal solution and preference evaluation results derived from F-TOPSIS calculated by Eqs. (21 and 22) are presented in Table 8. The relative closeness coefficient $\mathrm{CCi}^{+}$ values for the three alternatives are $A 1=(4.17)$, $A 2=(4.69)$, and $A 3=(0.25)$. The normalized values for the three ideal locations are $A 1=(0.88), A 2=(1.00)$, and $A 3=(0.05)$. This implies that location $A 2$ has the smallest gap for achieving the aspired/desired level among the three locations, whereas $A 3$ has the largest gap. Thus, $A 2$ is the ideal location followed by $A 1$ and $A 3$.

The methodology used in this study is superior since it has the capability of representing vague data. In multicriteria problems, a decision-maker may encounter enormous difficulty in quantifying imprecise and fuzzy data. Our proposed methodology easily quantifies these types of data. It includes an effective method to weigh the criteria and rank the alternatives to find the optimal solution. Thus, the proposed method presented in this paper can be applied to landfill site selection for MSW.

\section{Conclusion}

Management of MSW is a public issue, which requires efficient planning and operation. Landfill site selection is the crucial element of MSW management. Landfills have a direct bearing on the environmental health of the locality. The complexity involved in the landfill site selection process due to various parameters to be considered makes it necessary to apply sophisticated mathematical modeling for the decision making process.

This study provides a systematic decision making process for selecting an alternative MSW disposal location in the city of Mumbai, considering all aspects of MSW management in a holistic way. At present, there is no standard method of site evaluation due to diverse, complex factors and parameters and the proposed MCDM-based methodology for best-suited landfill site selection fills a gap. 
1. In this study, the integrated fuzzy-AHP-TOPSIS methodology was employed. We first listed the criteria as per the standard procedures and compared the possible alternatives of waste disposal sites.

2. Three alternative locations were compared and the site that was optimal for the location was found. The integrated methodology was found to be advantageous compared to the existing methods since it reduced the uncertainty in decision making by taking care of incomplete information and qualitative variables along with managerial preferences.

3. The modeled integrated approach reduces the possibility of errors and uncertainty in the decision making and ranking process, and makes landfill site selection less time consuming.

\section{References}

Adamides ED, Mitropoulos P, Giannikos I, Mitropoulos I (2009) A multi-methodological approach to the development of a regional solid waste management system. J Oper Res Soc 60(6):758-770

Alavi N, Goudarzi G, Babaei AA, Jaafarzadeh N, Hosseinzadeh M (2013) Municipal solid waste landfill site selection with geographic information systems and analytical hierarchy process: a case study in Mahshahr County, Iran. Waste Manag Res 31(1):98-105

Al-Jarrah O, Abu-Qdais H (2006) Municipal solid waste landfill siting using intelligent system. Waste Manag 26(3):299-306

Antunes AP (1999) Location analysis helps manage solid waste in central Portugal. Interfaces 29(4):32-43

Aragonés-Beltrán P, Pastor-Ferrando JP, García-García F, PascualAgulló A (2010) An analytic network process approach for siting a municipal solid waste plant in the metropolitan area of Valencia (Spain). J Environ Manag 91(5):1071-1086

Aydi A, Zairi M, Dhia HB (2013) Minimization of environmental risk of landfill site using fuzzy logic, analytical hierarchy process, and weighted linear combination methodology in a geographic information system environment. Environ Earth Sci 68(5):1375-1389

Babalola A, Busu I (2011) Selection of landfill sites for solid waste treatment in Damaturu town-using GIS techniques. J Environ Prot 2(01):1

Banar M, Kose BM, Ozkan A, Acar IP (2007) Choosing a municipal landfill site by analytic network process. Environ Geol 52(4):747-751

Barlishen KD, Baetz BW (1996) Development of a decision support system for municipal solid waste management systems planning. Waste Manag Res 14(1):71-86

Caruso C, Colorni A, Paruccini M (1993) The regional urban solid waste management system: a modelling approach. Eur J Oper Res 70(1):16-30

Chambal S, Shoviak M, Thal AE Jr (2003) Decision analysis methodology to evaluate integrated solid waste management alternatives. Environ Model Assess 8(1):25-34

Chamodrakas I, Batis D, Martakos D (2010) Supplier selection in electronic marketplaces using satisficing and fuzzy AHP. Expert Syst Appl 37(1):490-498

Chang DY (1996) Applications of the extent analysis method on fuzzy AHP. Eur J Oper Res 95(3):649-655
Chang NB, Wang SF (1996) Solid waste management system analysis by multi-objective mixed integer programming model. J Environ Manag 48(1):17-43

Chang NB, Wei YL (2000) Siting recycling drop-off stations in urban area by genetic algorithm-based fuzzy multi-objective nonlinear integer programming modeling. Fuzzy Sets Syst 114(1):133-149

Chang NB, Parvathinathan G, Breeden JB (2008) Combining GIS with fuzzy multicriteria decision-making for landfill siting in a fast-growing urban region. J Environ Manag 87(1):139-153

Charnpratheep K, Zhou Q, Garner B (1997) Preliminary landfill site screening using fuzzy geographical information systems. Waste Manag Res 15(2):197-215

Chau KW (2005) Prototype expert system for site selection of a sanitary landfill. Civ Eng Environ Syst 22(4):205-215

Chen SH, Hsieh CH (2000) Representation, ranking, distance, and similarity of L-R type fuzzy number and application. Aust $\mathbf{J}$ Intell Process Syst 6(4):217-229

Cheng S, Chan CW, Huang GH (2002) Using multiple criteria decision analysis for supporting decisions of solid waste management. J Environ Sci Health Part A 37(6):975-990

Cheng S, Chan CW, Huang GH (2003) An integrated multi-criteria decision analysis and inexact mixed integer linear programming approach for solid waste management. Eng Appl Artif Intell 16(5):543-554

Coastal Regulation Zone (CRZ) Notification (2011) Ministry of environment and forests. Government of India

Colebrook M, Sicilia J (2007) Undesirable facility location problems on multicriteria networks. Comput Oper Res 34(5):1491-1514

Cram S, Sommer I, Morales LM, Oropeza O, Carmona E, GonzálezMedrano F (2006) Suitability of the vegetation types in Mexico's Tamaulipas state for the siting of hazardous waste treatment plants. J Environ Manag 80(1):13-24

Current J, Ratick S (1995) A model to assess risk, equity and efficiency in facility location and transportation of hazardous materials. Locat Sci 3(3):187-201

Das D, Srinivasu MA, Bandyopadhyay M (1998) Solid state acidification of vegetable waste. Indian $J$ Environ Health 40(4):333-342

Delgado OB, Mendoza M, Granados EL, Geneletti D (2008) Analysis of land suitability for the siting of inter-municipal landfills in the Cuitzeo Lake Basin, Mexico. Waste Manag 28(7):1137-1146

Eiselt HA (2006) Locating landfills and transfer stations in Alberta. INFOR 44(4):285-298

Eiselt HA (2007) Locating landfills-optimization vs. reality. Eur J Oper Res 179(3):1040-1049

Eiselt HA, Marianov V (2014) A bi-objective model for the location of landfills for municipal solid waste. Eur J Oper Res 235(1):187-194

Eiselt HA, Marianov V (2015) Location modeling for municipal solid waste facilities. Comput Oper Res 62(1):305-315

Ekmekçioğlu M, Kaya T, Kahraman C (2010) Fuzzy multicriteria disposal method and site selection for municipal solid waste. Waste Manag 30(8):1729-1736

Erkut E, Moran SR (1991) Locating obnoxious facilities in the public sector: an application of the analytic hierarchy process to municipal landfill siting decisions. Socio-Econ Plan Sci 25(2):89-102

Erkut E, Verter V (1995) Hazardous materials logistics. In: Drezner Z (ed) Facility location: a survey of applications and methods. Springer, New York, pp 453-466

Erkut E, Karagiannidis A, Perkoulidis G, Tjandra SA (2008) A multicriteria facility location model for municipal solid waste management in North Greece. Eur J Oper Res 187(3):1402-1421

Eskandari M, Homaee M, Mahmodi S (2012) An integrated multi criteria approach for landfill siting in a conflicting 
environmental, economical and socio-cultural area. Waste Manag 32(8):1528-1538

Frantzis I (1993) Methodology for municipal landfill sites selection. Waste Manag Res 11(5):441-451

Fuertes LA, Hudson JF, Marks DH (1974) Solid waste management: equity trade-off models. J Urban Plan Dev Div 100(2):155-171

Gemitzi A, TsihrintzisVA Voudrias E, Petalas C, Stravodimos G (2007) Combining geographic information system, multicriteria evaluation techniques and fuzzy logic in siting MSW landfills. Environ Geol 51(5):797-811

Geneletti D (2010) Combining stakeholder analysis and spatial multicriteria evaluation to select and rank inert landfill sites. Waste Manag 30(2):328-337

Gianniko I (1998) A multiobjective programming model for locating treatment sites and routing hazardous wastes. Eur J Oper Res 104(2):333-342

Gorsevski PV, Donevska KR, Mitrovski CD, Frizado JP (2012) Integrating multi-criteria evaluation techniques with geographic information systems for landfill site selection: a case study using ordered weighted average. Waste Manag 32(2):287-296

Gottinger HW (1988) A computational model for solid waste management with application. Eur J Oper Res 35(3):350-364

Guiqin W, Li Q, Guoxue L, Lijun C (2009) Landfill site selection using spatial information technologies and AHP: a case study in Beijing, China. J Environ Manag 90(8):2414-2421

Harvey DJ, O'Flaherty TG (1973) An analysis of solid waste transportation and disposal alternatives. INFOR 11(1):187-200

Hatzichristos T, Giaoutzi M (2006) Landfill siting using GIS, fuzzy logic and the Delphi method. Int J Environ Technol Manag 6(1):218-231

Herzog M (1999) Suitability analysis decision support system for landfill siting (and other purposes). In: Proceedings of the ESRI international user conference, San Diego, CA, USA

Hokkanen J, Salminen P (1997) Locating a waste treatment facility by multicriteria analysis. J Multi-Criteria Decis Anal 6(3):175-184

Hung ML, Yang WF, Ma HW, Yang YM (2006) A novel multiobjective programming approach dealing with qualitative and quantitative objectives for environmental management. Ecol Econ 56(4):584-593

Hwang CL, Yoon K (1981) Multiple attribute decision making methods and applications. Springer, Berlin

Javaheri H, Nasrabadi T, Jafarian MH, Rowshan GR, Khoshnam H (2006) Site Selection of municipal solid waste landfills using analytical hierarchy process method in a geographical information technology environment in GIROFT. Iranian J Environ Health Sci Eng 3(3):177-184

Jenkins L (1982) Parametric mixed integer programming: an application to solid waste management. Manag Sci 28(11):1270-1284

Jolai F, Yazdian SA, Shahanaghi K, Azari Khojasteh M (2011) Integrating fuzzy TOPSIS and multi-period goal programming for purchasing multiple products from multiple suppliers. J Purch Supply Manag 17(1):42-53

Kahraman C, Cebeci U, Ruan D (2004) Multi-attribute comparison of catering service companies using fuzzy AHP: the case of Turkey. Int J Prod Econ 87(2):171-184

Kao JJ, Lin HY (1996) Multifactor spatial analysis for landfill siting. J Environ Eng 122(10):902-908

Kontos TD, Komilis DP, Halvadakis CP (2003) Siting MSW landfills on Lesvos Island with a GIS-based methodology. Waste Manag Res 21(3):262-277

Kontos TD, Komilis DP, Halvadakis CP (2005) Siting MSW landfills with a spatial multiple criteria analysis methodology. Waste Manag 25(8):818-832

Lahdelma R, Salminen P, Hokkanen J (2002) Locating a waste treatment facility by using stochastic multicriteria acceptability analysis with ordinal criteria. Eur J Oper Res 142(2):345-356
Leao S, Bishop I, Evans D (2001) Assessing the demand of solid waste disposal in urban region by urban dynamics modelling in a GIS environment. Resour Conserv Recycl 33(4):289-313

Li YP, Huang GH (2006) An inexact two-stage mixed integer linear programming method for solid waste management in the city of Regina. J Environ Manag 81(3):188-209

Lin HY, Kao JJ (1998) A vector-based spatial model for landfill siting. J Hazard Mater 58(1):3-14

Lin CT, Chiu H, Chu PY (2006) Agility index in the supply chain. Int J Prod Econ 100(2):285-299

Maharashtra state pollution control board (MPCB) (2014) status of environment report. Government of Maharashtra, India

Mahini AS, Gholamalifard M (2006) Siting MSW landfills with a weighted linear combination methodology in a GIS environment. Int J Environ Sci Technol 3(4):435-445

Mahler CF, De Lima GSA (2003) Applying value analysis and fuzzy logic to select areas for installing waste fills. Environ Monit Assess 84(1-2):129-140

Makan A, Malamis D, Assobhei O, Loizidou M, Mountadar M (2012) Multi-criteria decision analysis for the selection of the most suitable landfill site: case of Azemmour, Morocco. Int J Manag Sci Eng Manag 7(2):96-109

Makan A, Malamis D, Assobhei O, Loizidou M, Mountadar M (2013) Multi-criteria decision aid approach for the selection of the best compromise management scheme for the treatment of municipal solid waste in Morocco. Int $\mathbf{J}$ Environ Waste Manag 12(3):300-317

Melo AL, Calijuri ML, Duarte IC, Azevedo RF, Lorentz JF (2006) Strategic decision analysis for selection of landfill sites. J Surv Eng 132(2):83-92

Miranda ML, Miller JN, Jacobs TL (2000) Talking trash about landfills: using quantitative scoring schemes in landfill siting processes. J Policy Anal Manag 19(1):3-22

Mitropoulos P, Giannikos I, Mitropoulos I, Adamides E (2009) Developing an integrated solid waste management system in western Greece: a dynamic location analysis. Int Trans Oper Res 16(3):391-407

Moeinaddini M, Khorasani N, Danehkar A, Darvishsefat AA (2010) Siting MSW landfill using weighted linear combination and analytical hierarchy process (AHP) methodology in GIS environment (case study: Karaj). Waste Manag 30(5):912-920

Muttiah RS, Engel BA, Jones DD (1996) Waste disposal site selection using GIS-based simulated annealing. Comput Geosci 22(9):1013-1017

Natesan U, Suresh ES (2002) Site suitability evaluation for locating sanitary landfills using GIS. J Indian Soc Remote Sens 30(4):261-264

Nema AK, Gupta SK (1999) Optimization of regional hazardous waste management systems: an improved formulation. Waste Manag 19(7):441-451

Nema AK, Modak PM (1998) A strategic design approach for optimization of regional hazardous waste management systems. Waste Manag Res 16(3):210-224

Norese MF (2006) ELECTRE III as a support for participatory decision-making on the localisation of waste-treatment plans. Land Use Policy 23(1):76-85

Ojha CSP, Goyal MK, Kumar S (2007) Applying fuzzy logic and the point count system to select landfill sites. Environ Monit Assess 135(1-3):99-106

Önüt S, Soner S (2008) Transshipment site selection using the AHP and TOPSIS approaches under fuzzy environment. Waste Manag 28(9):1552-1559

Padmaja V, Asadi SS, Reddy MA (2007) Integrated analytical hierarchy process-GIS model for landfill siting: a case study from India. In: Proceedings of 22nd international conference on solid waste technology and management, pp 155-166 
Rakas J, Teodorović D, Kim T (2004) Multi-objective modeling for determining location of undesirable facilities. Transp Res Part D Transp Environ 9(2):125-138

Ramu NV, Kennedy WJ (1994) Heuristic algorithm to locate solidwaste disposal site. J Urban Plan Dev 120(1):14-21

Raut RD, Bhasin HV, Kamble SS, Banerjee S (2011) An integrated fuzzy-AHP-LP (FAHLP) approach for supplier selection and purchasing decisions. Int J Serv Oper Manag 10(4):400-425

Rey M, Soriano P, Stampfli E (1995) The location of a storage facility stabilized waste: the case of the Suisse Romande. INFOR 33(1):50-62

Rodriguez JJS, Garcia CG, Perez JM, Casermeiro EM (2006) A general model for the undesirable single facility location problem. Oper Res Lett 34(4):427-436

Saaty TL (1977) A scaling method for priorities in hierarchical structures. J Math Psychol 15(3):234-281

Saaty TL (1980) The analytical hierarchy process. McGraw-Hill, New York

Saaty TL (1990) An exposition of the AHP in reply to the paper "remarks on the analytic hierarchy process". Manag Sci 36(3):259-268

Saaty TL (2000) Fundamentals of decision making and priority theory with the analytic hierarchy process, vol 6 . Rws Publications, New York

Saaty TL, Vargas LG (2000) Models, methods, concepts and applications of the analytic hierarchy process. Kluwer, Boston

Sadek S, El-Fadel M, Freiha F (2006) Compliance factors within a GIS-based framework for landfill siting. Int $\mathrm{J}$ Environ Stud 63(1):71-86

Şener B (2004) Landfill site selection by using geographic information systems. Masters thesis, Department of Geological Engineering, Middle East Technical University, Ankara, Turkey. https://etd.lib.metu.edu.tr/upload/12605409/index.pdf. Accessed 04 Jan 2014

Şener B, Süzen ML, Doyuran V (2006) Landfill site selection by using geographic information systems. Environ Geol 49(3):376-388

Shekdar AV, Krishnaswamy KN, Tikekar VG, Bhide AD (1991) Long-term planning for solid waste management in India. Waste Manag Res 9(1):511-523

Shih HS, Shyur HJ, Lee ES (2007) An extension of TOPSIS for group decision making. Math Comput Model 45(7):801-813

Siddiqui MZ, Everett JW, Vieux BE (1996) Landfill siting using geographic information systems: a demonstration. J Environ Eng 122(6):515-523
Stowers CL, Palekar US (1993) Location models with routing considerations for a single obnoxious facility. Transp Sci 27(4):350-362

Sumathi VR, Natesan U, Sarkar C (2008) GIS-based approach for optimized siting of municipal solid waste landfill. Waste Manag 28(11):2146-2160

Ting SC, Cho DI (2008) An integrated approach for supplier selection and purchasing decisions. Supply Chain Manag Int J 13(2):116-127

Tuzkaya G, Önüt S, Tuzkaya UR, Gülsun B (2008) An analytic network process approach for locating undesirable facilities: an example from Istanbul, Turkey. J Environ Manag 88(4):970-983

Vasiloglou VC (2004) New tool for landfill location. Waste Manag Res 22(6):427-439

Vuk D, Koželj B, Mladineo N (1991) Application of multicriterional analysis on the selection of the location for disposal of communal waste. Eur J Oper Res 55(2):211-217

Vuppala P, Asadi SS, Reddy MA (2006) Solid waste disposal site selection using analytical hierarchy process and geographical information system. Pollut Res 25(1):73

Wang YM, Elhag T (2006) Fuzzy TOPSIS method based on alpha level sets with an application to bridge risk assessment. Expert Syst Appl 31(2):309-319

Wichelns D, Opaluch JJ, Swallow SK, Weaver TF, Wessells CW (1993) A landfill site evaluation model that includes public preferences regarding natural resources and nearby communities. Waste Manag Res 11(3):185-201

Wirasinghe SC, Waters NM (1983) An approximate procedure for determining the number, capacities and locations of solid waste transfer-stations in an urban region. Eur $\mathbf{J}$ Oper Res 12(1):105-111

Wu HY, Tzeng GH, Chen YH (2009) A fuzzy MCDM approach for evaluating banking performance based on balanced scorecard. Expert Syst Appl 36(6):10135-10147

Xi BD, Su J, Huang GH, Qin XS, Jiang YH, Huo SL, Yao B (2010) An integrated optimization approach and multi-criteria decision analysis for supporting the waste-management system of the city of Beijing, China. Eng Appl Artif Intell 23(4):620-631

Yildirim V (2012) Application of raster-based GIS techniques in the siting of landfills in Trabzon Province, Turkey: a case study. Waste Manag Res 30(9):949-960 